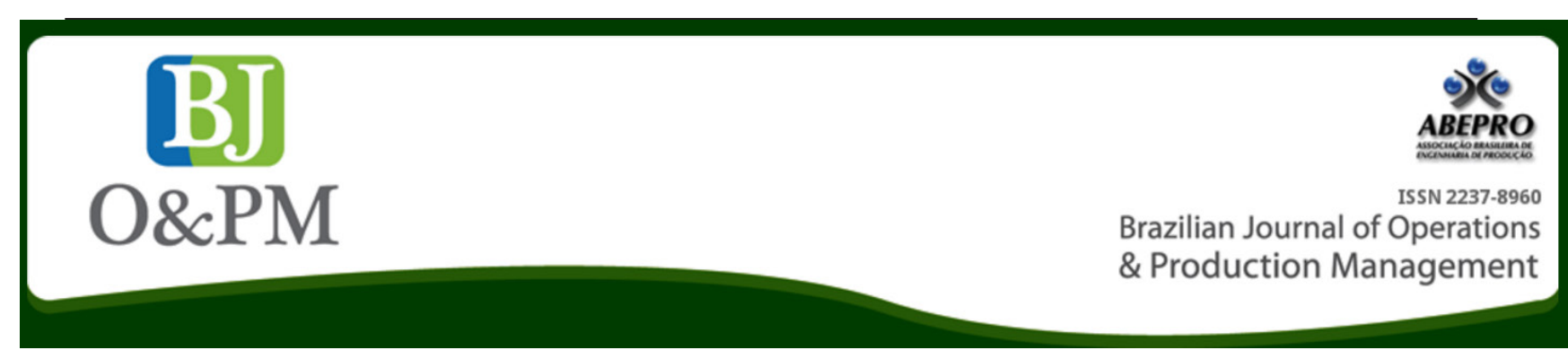

\title{
LIFE MICROINSURANCE IN BRAZIL: A PROPOSAL FOR PRICING AND ASSESSING THE TARGET AUDIENCE
}

Raphael Portilho Soares ${ }^{\mathrm{a}}$; Julio Vieira Neto ; Mirian Picinini Méxas ${ }^{\mathrm{a}}$; Tayana Aparecida Rigueira ${ }^{\mathrm{a}}$

a Fluminense Federal University (UFF) - Niterói, RJ, Brazil

\section{ABSTRACT}

The purpose of this article is the creation of a pricing model for life micro-insurance, as well as the analysis of its market potential in Brazil. In this sense, we sought to address issues relating to a biometric table used for pricing, such as the financial impact that the hiring value of this type of product reflects on family income. In addition, it is intended to expose the anti-selection risk made by the insurer, as well as the difference between the premium values for male and female genders, as women outlive men according to life tables published by the Instituto Brasileiro de Geografia e Estatística (IBGE) (Brazilian Institute of Geography and Statistics).In the development of the research, the methodology adopted was an exploratory, documental study by means of a qualitative research on the micro-insurance theme, especially life insurance, as well as the elements used in the measurement of insurance. It can be concluded in this work, that the financial impact on family income is not relevant, especially when the premium is parceled monthly according to the terms of the proposed product, making it accessible.

Keywords: Microinsurance, Pricing, Biometrics Board, Life Insurance, Market Potential 


\section{INTRODUCTION}

Insurance arises from the need of men to preserve their assets from adverse events. The Babylonian merchants in the thirteenth century BC are seen as the forerunners of the concept of risk sharing, since, worried about the risk of losing their camels because of their work activities, they have signed agreements so that in case of loss, disappearance or death of the animal, the camel driver would receive another camel paid by other breeders. Another version similar to the camel is the Phoenicians' and their vessels. In order to preserve their ships and their cargoes, they firmed agreements; thus, in case of loss suffered by one of the group members, such loss would be restored by the other members (SILVA, 2008).

In Brazil, the first insurance company - Boa Fé Insurance Company - appeared in Bahia in 1808 with the arrival of the Portuguese royal family, who had come to the Tupinikim land fleeing from the Napoleonic troops that threatened to take the Portuguese throne. However, until the moment in which Brazil became independent from Portugal in 1822, all insurers that arose were subordinate to the Lisbon Insurance House (SOUZA, 2007).

Given the context, the insurance reduces the fragility of policyholders to the extent that the losses are replaced by premium payments. Thus, micro-insurance becomes one of the options that households with low purchasing power have to manage the various risks to which they are exposed.

The difference between micro-insurance and conventional insurance is that the former is used by people from lower social classes with fewer financial reserves and a fairly buoyant income over time. However, this mode comes after the microcredit experiences in other countries, mainly in Bangladesh that was the birthplace of the new concept of microcredit, which, as well as micro-insurance, is one of the branches of microfinance.

Given this concept, micro-insurance emerges as an alternative to favor economic growth and human development, in addition to making financial systems more accessible to low-income population, not including government programs of social welfare. This type of insurance is not limited to any particular risk, since it covers a vast nature of risk, provided it is something insurable and that coverage can be structured to be financially viable and accessible to its target audience. However, the Superintendência de Seguros Privados (SUSEP) (Superintendence of Private Insurance) defines the types of coverage that can be contracted in micro-insurance policies (COUNTER, 2010).

The first publication with the term micro-insurance occurred around 1999 and the development on this subject has been the subject of several debates by various groups around the world.
Micro-insurance target audience is very specific since it is related to the low-income population, and insurance products and services on the market follow the same principles of insurance accepted in the market.

The regulation and control of this activity in Brazil are under the responsibility of SUSEP, an agency of the Sistema Nacional de Seguros Privados (SNSP) (Private Insurance National System), responsible for security policy dictated by the National Council of Private Insurance, and which has the duty to supervise the creation, organization, functions and operations of business companies which have the operation of private insurance as their object (SILVA, 2008).

In Brazil, on September 21, 2004, SUSEP Circular 267/2004 was a milestone of the beginning of the regulation, the first standard for the popular insurance (BRAZIL, 2004). It is important to clarify that the popular insurance and microinsurance are not synonymous, since the first is characterized by low levels of premiums and coverage, unlike the concept of micro-insurance.

Micro-insurance has similar characteristics to the social protection programs of the government intended to the lowest income layers, however, it is a product of the insurance market for commercial purposes and, therefore, profitable.

According to Sepulveda et Afonso (2009), in Brazil, there are several popular insurance services that could be classified as micro-insurance; their costs are lower than $R \$ 10,00$ per month, and they are typically offered by retailers, electric energy and telephone utility companies, and popular banks.

This research is based on the development of the pricing proposal for life micro-insurance, in order to identify the financial impact on the income of individuals when buying this protection, as well as to analyze its market potential.

This article covers two goals. The first is to conceptualize and price life micro-insurance in Brazil for some values whose amounts are insured, checking the economic and financial impact on the family income. In this case the insured has the option of paying for the premium a single payment or up to five payments in order for a coverage of one year against the death event. This is done using valuation techniques based on actuarial methodologies. The second is to assess the market potential for this product.

\section{THEORETICAL FOUNDATION}

\subsection{Insurance}

The securitarian process emerges through a cultural activity linked to merchants who were concerned in terms of protecting their property from possible risks/fatalities that could occur in bad faith of their opponents, or from natural causes. 
Insurance is therefore the result of the human need focused on security of goods of life directed to the exercise of commerce. Thus, historically, the Insurance Institute was born into the trade as an instrument that can ensure the preservation of production stations and flow of wealth (SILVA, 2008, p.1).

Life insurance also appeared in England, where they created the first insurance companies in the format that is known nowadays (SOUZA, 2007).

According to Ferreira (1985), the life insurance idea was originated in the "mutual aid societies" formed in distant times. Then, around the seventeenth century these organizations came up with the name of tontines, which, compared to the primitive organizations from the time of Domitius Ulpiannus (mayor of Rome and considered the first actuary in history), they presented some changes in terms of the technical structure.

For Merino et al. (2002), in 1725 Abraham de Moivre had the prerogative to calculate the premiums of life insurance with scientific bases. In 1775, fifty years later, it was left to James Dobson to calculate premiums for different life insurance, as well as the mathematical reserves ${ }^{1}$ arising from insurance. Thus, for the first time it was established a global model applied to the systematization of a company life insurance, which guaranteed its existence and economic and financial stability in the near future.

\subsubsection{Insurance in Brazil}

In Brazil, the first guidelines of insurance contracts date back to around 1665, and the first insurance company in the country was the Boa Fé Insurance Company. However, until the mid-nineteenth century, the country did not have its own legislation, and because of this absenteeism, the insurance contracts of the time followed the guidelines of contracts in general, by means of the application of the Roman origin principle that the contract is law between the parts.

For Silva (2008), the opening of a set of rules characteristic of the Brazilian trade is Law No. 556 of 25 June 1850, establishing the Brazilian Commercial Code which only dealt with marine insurance, but clearly established rights and obligations between the parties.

According to Guimarães (2004), the implementation of the Commercial Code was of paramount importance for the development of insurance in Brazil, encouraging the emergence of numerous insurance companies, which operated not only with the marine insurance, expressly conjectured in jurisprudence, and also with the terrestrial insurance

1 Present value of future commitments of the company towards its customers, which may correspond to known values or estimates, allocated in the company's liabilities (see Ferreira and Cantanhede, 2009).
Ferreira (1985) explains that the life insurance industry exercise had its action postponed in Brazil, for having been conjectured as an immoral speculation for a long time. The Brazilian Commercial Code, by means of the Law 556 of 25 June 1850, relating to the field of marine insurance, states:
"Art. 686 - Insurance is prohibited (...)
2- About the life of any free person.
Prohibiting it, the mentioned law absolutely nullified any such contract; it allowed, however, the insurance of slaves' lives for considering them as things and not people ${ }^{2}$. In 1855 life insurance began to evolve because of the emergence of "Tranquilidade Company", the first company founded in Brazil which marketed life insurance for free people."

Decree-Law No. 73 of November 21, 1966, consolidated the insurance legislation of the country and presented general rules of the insurance activity on national soil. Within this context, in the article $7^{\text {th }}$ of the insurance law, as this decree is also known, gave rise to SNSP, and the doctrine which is the Union's private aptitude gave rise to the formulation of private insurance, legislation on its general rules and supervision of operations in the insurance market (SILVA, 2008).

The Brazilian insurance market has changed a lot, adapting itself to the new economic conjecture to which the country is inserted and the soft market. Insurers are characterized by dealing with the most diverse lines of business, and the personal insurance sector represents the largest share of this market volume of premiums collected. This fact is illustrated in Figure 1, which presents the projection of the representation of the volume of premiums written ${ }^{3}$, according to the Conselho Nacional de Seguros Privados (CNSeg, 2014) (National Council of Private Insurance):

\section{COLLECTION PROJECTION 2016}

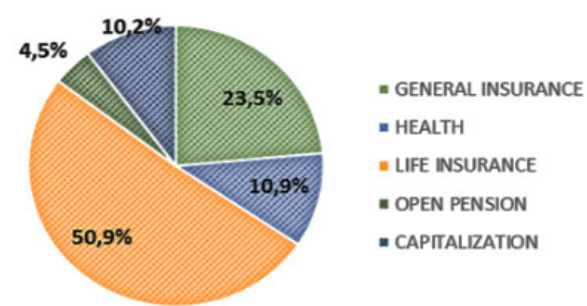

Figure 1. Division by segment: revenue projection, 2016 Source: Adapted from CNseg (2014)

The data for the projections were made by CNSeg, in a scenario in which it is expected that Brazil will grow slightly, with the gross domestic product (GDP) growing by $3.1 \%$ in 2013 and $4 \%$ in 2016.

2 See Ferreira (1985), page 38.

3 For insurance, we include the premiums of direct insurance, plus the accepted and retrocession coinsurance, and less the ceded coinsurance, refunds and returns. 


\subsection{The microcredit}

Microcredit is the credit grant of low-value to small entrepreneurs and low-income people and who cannot offer real guarantees without access to the traditional financial system, being thus directed the production of working capital and guarantee producer in times of crisis (CALDAS, 2003).

Also according to Caldas (2003), the most popular classes from all continents cultivate the same practice of savings, thus building up informal groups whose members are obliged to save a certain amount of money which is then collected by a representative, responsible for saving the accumulated amount. By achieving the previously agreed amount through a sweepstakes, they define which caste member is entitled to use the loan to run his business. Based on these models and consortia, in addition to the model used by the churches and parishes in the last century, who financed the farmers in times of crisis, there were organizations in several countries. In this movement, the most famous case is the experience of Bangladesh.

In the 1970s, Professor PhD. Muhammad Yunus was an economics teacher at the University of Chittagong in Bangladesh, a small but populous country in the Indian subcontinent. Yunus and his students peered what was happening in the small village of Jodra, located next to the university. As a result of this research, they noted that the struggle for survival was more laborious for the plebs due to the lack of equity and the inability to obtain loans at commercial banks to support productive activities, leaving the with the only option of subjecting themselves to high and abusive interest charged by loan sharks (YUNUS, 2006).

\subsection{Microinsurance in Brazil}

In Brazil, although the agents working with microcredit and micro-insurance mainly are few, the customer volume growth rates are quite high compared to traditional credit segments.

Micro-insurance comes as an option to provide development, economic and human development, as it is on the border between the social protection offered by the government and financial services. As the other segments of microfinance, such as micro-credit and savings that help individuals to move and get resources, micro-insurance appears to protect acquired assets, becoming thus a vehement social inclusion tool (COUNTER, 2010).

Despite the fact that people of lower classes face different risks, managing them through personal savings, loans, social protection networks or through illegal ways, in recent years these people have gained access to credit offered by financial institutions. These financial organizations perceived the need for this market niche that was not previously explored by the companies and realized that this class is demonstrating the ability to make and keep commitments. Still, despite being an inclusive tool, do not take microinsurance as a welfare program, given the fact that you have to pay premiums in exchange for the protection offered by the insurance company (COUNTER, 2011).

In Brazil, "the determination of the National Central Bank that $2 \%$ of demand deposits of banks were targeted to microfinance operations contributed decisively to the growth of credit to low-income customers, stimulating insurance moneylenders life" (COUNTER, 2011).

SUSEP, by means of the SUSEP Circular No. 440 of June 27,2012 , authorized the marketing of various types of micro-insurance. In the non-life insurance group and in the life micro-insurance group, the insurance companies can provide coverage for the following items described in Table 1.

\begin{tabular}{|c|c|}
\hline \multicolumn{2}{|c|}{ Types of Microinsurance } \\
\hline Non-Lifemicroinsurance & Life Microinsurance \\
\hline Electrical damage & Serious diseases \\
\hline $\begin{array}{l}\text { Windstorm, hurricane, cyclone, } \\
\text { tornado and hail }\end{array}$ & $\begin{array}{l}\text { Spouse and dependents } \\
\text { inclusion }\end{array}$ \\
\hline Daily rates by fire & Travels \\
\hline Small vessel and fishing net & Unemployment \\
\hline $\begin{array}{c}\text { Civil family for damages caused to } \\
\text { others }\end{array}$ & Fees for hospitalization \\
\hline Full and partial collapse & Daily rates temporary disability \\
\hline $\begin{array}{c}\text { Liability for accidents related to the } \\
\text { use and conservation of the property } \\
\text { that causes damage or harm to } \\
\text { others }\end{array}$ & $\begin{array}{l}\text { Medical, hospital and/ } \\
\text { or dental expenses due to } \\
\text { personal accident (DMHO) }\end{array}$ \\
\hline $\begin{array}{l}\text { Rent payment to those affected by a } \\
\text { covered risk }\end{array}$ & $\begin{array}{c}\text { Permanent and total disability } \\
\text { by accident (IPTA) }\end{array}$ \\
\hline $\begin{array}{c}\text { Extra costs and expenses with } \\
\text { documentation due to a risk } \\
\text { occurred }\end{array}$ & $\begin{array}{l}\text { Reimbursement of funeral } \\
\text { expenses }\end{array}$ \\
\hline $\begin{array}{l}\text { Temporary loss of income of the } \\
\text { insured client in the event of fire, } \\
\text { lightning or explosion that made } \\
\text { it impossible to continue working } \\
\text { temporarily in the damaged property }\end{array}$ & $\begin{array}{c}\text { Delays in school and college } \\
\text { tuitions }\end{array}$ \\
\hline $\begin{array}{l}\text { Theft and/or robbery of the insured } \\
\text { client's property assets while in the } \\
\text { interior of the property including } \\
\text { damage to the very property in case } \\
\text { of such events or in case of a simple } \\
\text { attempt }\end{array}$ & $\begin{array}{l}\text { Accidental death, solely; } \\
\text { Natural death or accidental } \\
\text { (coverage that will be } \\
\text { addressed in the price setter } \\
\text { ahead) }\end{array}$ \\
\hline
\end{tabular}

Source: Adapted from Brazil, 2012 - SUSEP Circular No. 440, of June 27, 2012

According to studies carried out by the Consultative Committee on Micro-insurance of the Conselho Nacional de Seguros Privados (CNSP) (National Council of Private Insurance), it was clarified that the term "micro-insurance" is the insurance protection delivered by entities authorized to operate in the country, aiming to protect the socio-economic 
status, through payments of proportional premiums to the possibilities of occurrence of an accident and the costs involved in the commercialization, in accordance with the principles and the generally accepted law.

\subsection{Individual Life Insurance}

The individual life insurance provides coverage to be offered to a single individual, whether in case of survival or in the event of death, which will be addressed later in this work. Despite having as its main characteristic the individuality in terms of the membership, this type of insurance can cover more than one person, as a couple or in the case of members of a company. Souza (2007) defines these cases as insurance in conjunction or two or more individuals, which cannot be mistaken with group life insurance.

In Brazil, SUSEP regulates this type of insurance through the CNSP Resolution No. 117/2004, which brings in its main section the following text: "it amends and consolidates the operating rules and criteria for operating risk coverage offered in life insurance plan, and takes other measures".

In case of death the insurance can be broadly categorized into two dissimilar sets according to Ferreira (1985):

I) Lifelong Individual Life Insurance - it covers the risk of death regardless of the time of death of the insured;

II) Temporary Individual Life Insurance - it covers the risk of death for a certain period of contract, therefore, beneficiaries are only entitled to compensation in case the insured dies during the contractual period.

Insurances also express an analysis as to the time in which the policy will enter into force, which may be immediate or after a predefined period on a deferred basis as shown in Figure 2.
According to Guimarães (2004), the pricing of individual life insurance is performed by analyzing a number of factors that considers such particular form of insurance. For being unique, this insurance modality demands a more detailed analysis to investigate the various data that must be evaluated by the subscription of the insurance company.

\section{METHODOLOGY}

The object of this research as described in the introduction, aims to analyze the market potential and proposes a pricing methodology for life micro-insurance, using a documentary research on the basis of the Instituto Brasileiro de Geografia e Estatística (IBGE) (Brazilian Institute of Geography and Statistics), data of the Pesquisa Nacional por Amostra de Domicilios (National Survey by Household Sampling) (PNAD) and the biometric tables of the Experiência do Mercado Segurador Brasileiro (BR-EMS) (Brazilian Insurance Market Experience) male and female for mortality developed by the Federal University of Rio de Janeiro (UFRJ), SUSEP Statistics System basis and the Confederação Nacional das Empresas de Seguros Gerais (National Confederation of General Insurance Companies) database, Life and Private Pension, Supplementary Health and Capitalization.

In addition, documentary research was conducted and an exploratory study based on a literature review that, according to Gil (2008), aims to clarify and modify concepts and ideas, based on the formulation of searchable conjectures for further studies.

The bibliographic and documentary research provide the preparation of the price setter that is considered as the proposal to meet the proposed objectives in this research.

As for the data, this research is classified as quantitative, since according to Jung (2003), this procedure is widely discussed to support empirical studies in science in general. In the view of Creswell (2003), the quantitative research

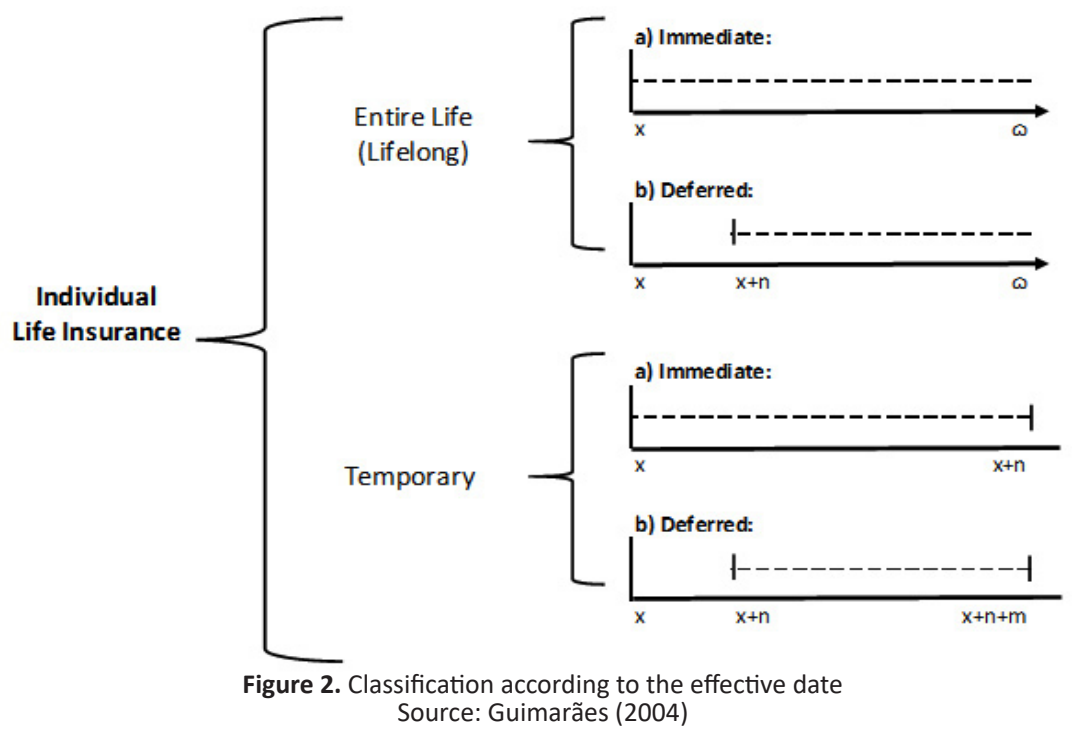


aims to identify the variables proposed by the study in order to relate the samples and compare them.

In this sense, the data were extracted from the historical projections of the BR-EMS biometric tables, attached to SUSEP Circular 402 of March 18, 2010.The desk research, using IBGE data, was removed from the PNAD, which obtains information on socioeconomic characteristics of the population.

Another important aspect is the choice of the qualitative research, as it brings to the universe researched a theoretical approach and produces information based on quantitative data analysis and of the pricing model applied.

The data extracted from the CNSeg projections history were used to explain the projection of the insurance market for subsequent years, for the market for insurance such as life, non-life and capitalization.The BR-EMS Biometric Board was used in preparing the price setter: both boards regarding female and male mortality.

In this sense changes regarding the original value of the probabilities of the board were held, due to the worsening added from the premium installment option by the insured. The data extracted from the IBGE and PNAD refer to the population quantitative of individuals who are potential consumers of micro-insurance, as well as data to estimate the potential target audience. Population data were also taken from the IBGE and, from the PNAD, population and income data, in order to frame the eligible persons to their right to micro-insurance, according to the legislation.

\section{DEVELOPMENT OF THE PROPOSED MODEL AND TARGET AUDIENCE}

The model proposed by this research was developed following some actuarial assumptions and the analysis of its target audience followed the niche of people that fall into the definition of SUSEP as the micro-insurance public target.

In this sense, it presents a pricing model for microinsurance life with a one-year term as a time parameter, whose payment of the insured amount is performed in a single way to beneficiaries, in case they die along a certain age, that is, without reaching age $x+1$.

According to Ferreira (2010), the concepts involved in the calculation of the premium are varied, and there are three types of premium, as shown below:

Risk Prize: the one that covers the average risk;

Pure Premium: it is the risk premium added of a security charge to cover any risk fluctuations;

$>$ Commercial premium: it is the pure premium plus a loading for the payment of expenses, including the portion of the profit expected.
Of the pricing of life micro-insurance a value called premium is generated. This value is in fact paid by the insured for a given coverage and the insured amount previously defined in the contract. This final value is called commercial premium and its equation is described below.

This type of insurance uses the cash basis, where revenues are estimated for one year in order to meet future expenditure and that will occur within the same year. The actuarial flow is represented in Figure 3:

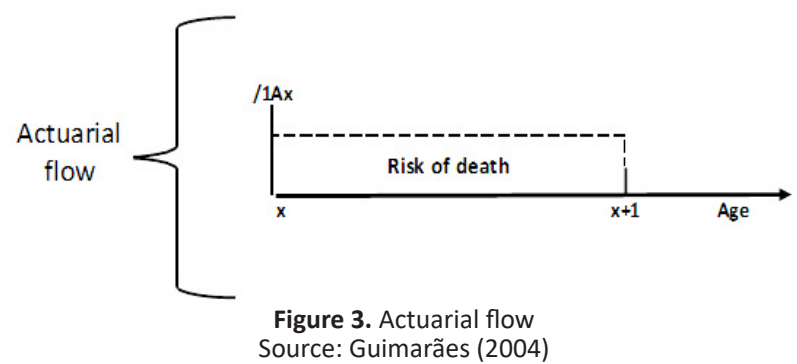

To calculate the proposed insurance the following actuarial formula was used in its development:

$$
\ln \mathrm{A} x=\frac{M x}{D x}-\frac{M x+n}{D x} \text {. Insured Capital }
$$

Where: $/ 1 \mathrm{Ax}=\frac{M x}{D x}-\frac{M x+1}{D x}$

In which,

$x=$ age of the insured;

$\mathrm{n}=$ period;

$\mathrm{IX}=\mathrm{It}$ represents the number of people alive at age $\mathrm{x}$;

$v^{x}=1 /(1+i)^{n}$ (financial update of the future gain);

$D x=1 \mathrm{x} . v^{x}$;

$C x+t=v^{x+t+1} \cdot d x+t$ (It represents the number of the deceased until the end of the first year, adjusted by interest rate);

$$
M x=\sum_{t=0}^{\infty} C x+t
$$

$/ 1 A x=$ Life insurance temporary for 1 year

To calculate the pure premium, the formula described above was used and it was multiplied by the importância segurada (IS) (insured amount) determined by the insured and the maximum value for the micro-insurance coverage in case of death is $R \$ 30,000.00$. This value is provided in the SUSEP Circular No. 490 of June 27, 2014, which amended the SUSEP Circular No. 440, of June 27, 2012.

To calculate the commercial premium, which includes the percentage for administrative expenses, brokerage commissions and profit, a shipment $\propto=30 \%$ was arbitrated. Thus, the final formula has taken the following configuration, pointing out that a safety loading was not adopted: 


$$
1 A x=\left(\left(\frac{M x}{D x}-\frac{M x+1}{D x}\right) . \text { Insured Capital }\right) /(1-\alpha)
$$

In the price formation it is possible to divide the commercial premium in up to five times without interest, that is, at the end of the calculations, there is the option of choosing the number of equal installments the client wants to pay the premium. The formula used for this is as follows:

\section{Final Prize $=($ Commercial Prize $) / n$ times}

To apply this formula in the pricing was necessary to use an actuarial table, in this case the male and female BR-EMS Biometric Board for mortality; and in both an actual rate of $4.68 \%{ }^{4}$ interest was applied. This value was determined based on the real interest rate in Brazil in December 2014, which purges the effect of inflation that is around $6.55 \%$.

CNSP Resolution No. 201/2008 amending and consolidating the operating rules and criteria for the operation of coverage for death and disability offered in open complementary social security plans, states in its ninth article, paragraph two, that the biometric reference to mortality is the AT- 83 (male), as the minimum mortality rate. However, there are currently countless tables used by the insurance market, such as the AT- $83^{6}$, AT- $2000^{7}$ and BR-EMS, in addition to those used for calculating the social security factor developed periodically by IBGE.

The BR-EMS, table developed by UFRJ, took into account the history of survival and mortality of the participants of private complementary social security plans and Brazilian consumers of life insurance. It replaces American tables used by the market, given that they express a distortion of the Brazilian population scenario: foreshadow an expectation of survival that does not correspond to the reality experienced by the Brazilian market.

The BR-EMS estimates that the life expectancy of a Brazilian man of 40 years (average age of a life insurance buyer in Brazil) is more than 40 years, while the AT2000 presumes 33.5 years. Among Brazilian women, life expectancy at age 40 is over 46.2 years, according to BREMS, while the American table estimated 38.8 years (Rio Pesquisa, Year III, No. 51- FAPERJ).

4 http://oglobo.globo.com/economia/brasil-continua-com-maior-taxareal-de-juros-do-mundo-14732703 (accessed in December 30, 2014).

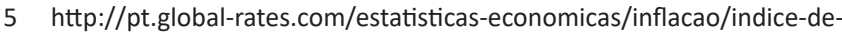
precos-ao-consumidor/ipc/brasil.aspx (accessed in December 12, 2014).

6 Annuity Table 1983 (AT-83): This is an update of the table AT-49, whose period of observation was from 1971 to 1976, and an update of the AT-49 table, with representation of the average life expectancy of 78 years (Chan, Silva and Martins - $6^{\text {th }}$ Controllership and AccountingCongress USP).Apud $<$ http://www.soa.org>

7 Annuity Table 2000 (AT-2000): It is an American table, made from an update of the table AT-83, used in Brazil, in which the third table belongs to the AT group, with representation of an average life of 84 years (Chan, Silva and Martins $-6^{\text {th }}$ Controllership and Accounting Congress USP). Apud - <http://www.soa.org>

\subsection{Target Audience}

The target audience for micro-insurance is basically composed of people with incomes up to three minimum wages, that is, people in classes C, D and E (in 2014 the minimum wage was R\$ 724.00 or US\$226.001). In Brazil, since 2001, large insurers have offered products for people of these classes (MICRO-INSURANCE, 2010).

According to PNAD 2013 data, the potential market for micro-insurance would be about 97.8 million people, considered as potential buyers for fitting in the group whose per capita monthly income is up to 3 minimum wages, as shown in Figure 4. It is worth noting that the analysis of market potential takes into account that all people are probable consumers of the product exposed in this research.

\section{Average Monthly Income}

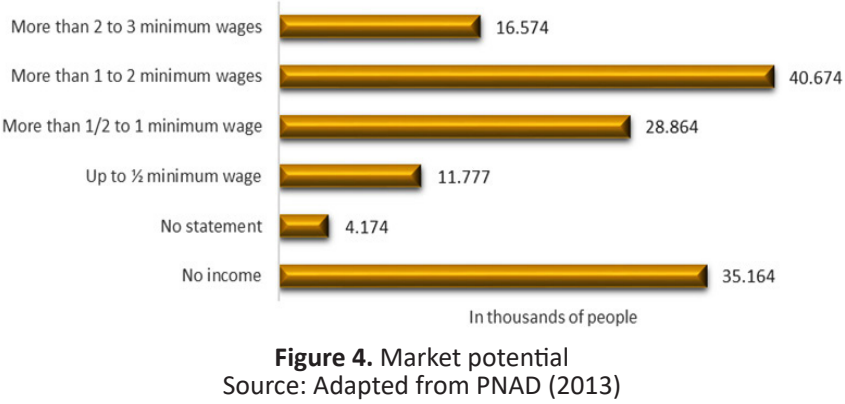

The Brazilian people have an aversion to the term "death" and have a great passion for life, yet the growth potential of this market still has a lot to be explored by insurers (COUNTER, 2011).

\section{RESULTS ANALYSIS}

This section is meant to examine the financial impact, as well as to measure the actual effect of the purchase of the proposed insurance in the financial life of the individual, that is, determine the percentage of income that would be compromised when buying life protection through microinsurance.

With respect to pricing, tests were conducted for two different ages, 18 and 45 and also a comparison between the prices indicated in pricing, for both sexes, thereby determining the financial impact that they bring to different types of income up to three minimum wages. It is noteworthy that the choices of the above ages were made randomly, and an early age for the purchase of insurance and a median age of the table were chosen.

For the pricing of two people of opposite sexes aged 18, the maximum amount of $\mathrm{R} \$ 30,000.00$ (US\$ 9,360.00) of insured capital was considered for the tests. Thus, for the death coverage for any reason hired by the male insured aged 18 years, the premium paid by him so he can be entitled 
to this insurance is $R \$ 37.95$ (US\$11.84) in a single payment; however, he still has the opportunity to split this premium in up to 5 times, which reduces even more the impact of contracting this type of insurance on his household income.

The income of the insured person should be half the minimum wage, that is, $\mathrm{R} \$ 362.00$ (US\$112.94). The impact of contracting this insurance in the monthly income would be $10.48 \%$, opting to pay for it in only one installment. In case of payment in five times, the monthly premium would be R\$7.59 (US\$ 2.37). A decrease of $501.44 \%$ over the amount paid in the month for insurance, thus compromising only $2.10 \%$ of their income for five months in order to be entitled to protection for one year.

The aforementioned insured should receive a minimum wage ( $R \$ 724.00$ or US\$226.00). The impact of the insurance amount paid only once in their family income would be $5.24 \%$.If the insured received three minimum wages, that is, $\mathrm{R} \$ 2,172.00$ (US\$ 677.67), the impact of the insurance amount on the income would be $1.75 \%$; however, if he chooses to spread the insurance in five times the impact on his monthly income would be $0.35 \%$ during the five months.

As life insurance for women has a more affordable value due to their longer survival, the amount to be paid by the insured shall be R\$15.30 (US\$ 4.77) in a single installment, or R\$3.06 (US\$ 0.95) monthly for five months. Should they receive half the minimum wage, the impact on their income would be $4.22 \%$ if the insurance was paid for in one payment, and $0.85 \%$ if paid in five times.

For pricing the 45-year-old insured persons, the values generated are slightly higher, as the probability of death is greater than for the underage insured individuals.

The amount of the premium for a 45-year-old insured would cost R\$ 115.97 (US\$ 36.18), well above the calculated value for the 18-year-old insured. Thus, the installment payment constitutes attractiveness maintenance option and less impact on the monthly income of the individual.

For a 45-year-old woman, the final premium would be $\mathrm{R} \$ 53.76$ (US\$ 16.77), given their greater life expectancy. That said, insurance is more affordable for the female audience and causes less impact on financial income than the insurance contracted by the male audience.

\section{CONCLUSION}

This article was aimed to conceptualize and price microinsurance for life insurance in Brazil, for some insured amount values, and assess the financial impact and the market potential of this product. Through the calculations performed on the model, the following results were determined: a) The financial impact on the family structure is shown in a low degree, since, in certain cases in which the income is up to half the minimum wage, lower installments represented $3 \%$ of the monthly income when the insured has opted for the installment of the premium;

b) The pricing was performed using biometric tables with the characteristics of the Brazilian population, and thus being fairer to the profile of the population and demonstrating an accessible product to the low-income population groups, including various coverage options for the insured;

c) The potential market for micro-insurance life is quite extensive, making it attractive for insurers to have the interest of offering the product.

Although the results have shown promising results, especially after verifying its market potential, a greater mass of information for product commercialization is required. This is because it has good representation among social classes with higher income.However, it is still little known among the lower social classes.

Nevertheless, for the success of life micro-insurance and so that the Brazilian insurance companies have an interest in marketing it, it is necessary to overcome obstacles and create mechanisms for the development, dissemination of the importance of insurance and the implementation of ideas and marketing actions, as well as the reduction of the tax burden in order to increase the interest and access to the product by the low-income population. With the construction of a more inclusive financial system with greater product offering, which goes beyond microcredit services, but which could also reach the micro-insurance market, it would be possible to increase the capillarity of financial services to the poorest population, in addition to ensuring greater access to information on the services offered.

\section{REFERENCES}

Alvim, P. (1983). O contrato de seguros. São Paulo: Ed. Manuais Técnicos de Seguros.

Baars, G.; Sennett, N. (1993). The fundamental of group insurance. Zurich: Swiss Reinsurance Comapany.

Banco do Povo Paulista (2015). Muhammad Yunus o banqueiro dos pobres. Available in: <http:// www.bancodopovo.sp.gov.br/statico/arquivos/bpp_ download_005.pdf>. Access: 15/11/2015.

Brasil (1850). Lei n. 556, de 25 de junho de 1850. Institui o Código Comercial.

Brasil (1966). Decreto-Lei № 73, de 21 de Novembro de 1966. Dispõe sobre o Sistema Nacional de Seguros Privados, 
regula as operações de seguros e resseguros e dá outras providências.

Brasil (2002). Lei n. 10.406, de 10 de janeiro de 2002. Institui o Código Civil.

Brasil (2004). Circular SUSEP № 267, de 21 de Setembro de 2004. Estabelece as regras de funcionamento e os critérios para operação do seguro de vida em grupo popular e disponibiliza, no site da SUSEP, suas condições gerais padronizadas e respectivos parâmetros.

Brasil (2004). Resolução CNSP № 117 de 2004. Altera e consolida as regras de funcionamento e os critérios para operação das coberturas de risco oferecidas em plano de seguros de pessoas, e dá outras providências.

Brasil (2008). Resolução CNSP № 201, de 16 de Dezembro de 2008. Altera e consolida as regras de funcionamento e os critérios para operação das coberturas por morte e invalidez oferecidas em planosde previdência complementar aberta e dá outras providências.

Brasil (2010). Circular SUSEP № 402, de 18 de Março de 2010. Dispõe sobre a aprovação dos critérios de elaboração e atualização das tábuas biométricas BR-emssb-V.2010-m, BRemssb-V.2010-f, BR-emsmt-V.2010-m e BR-emsmt- V.2010-f.

Brasil (2012). Circular SUSEP № 440, de 27 de Junho de 2012. Dispõe sobre os parâmetros obrigatórios para os planos de microsseguros e suas formas de contratação, inclusive com a utilização de meios remotos, e da outras providências.

Brasil (2014). Circular SUSEP № 490, de 27 de Junho de 2014. Dispõe sobre alterações na Circular SUSEP no 440 de 27 de junho de 2012.

Cacciamali, M. C.; Chahad, J. P. Z.; Tatei, F. (2008). Microfinançase Política Pública na América Latina. Cadernos PROLAM/USP São Paulo, vol.1, ano 8, p. 149 - 172, 2008.

Caldas, E. (2014). Da experiência do microcrédito à microfinança. Available in: <http://www.polis.org.br/ uploads/802/802.pdf>. Access: 27/12/2014.

Chan, B. L.; Silva, F. L. da; Martins, G. de A. (2006). Tendência de Aumento da Expectativa de Vida e a Solvência das Entidades Abertas de Previdência Complementar. 6o Congresso USP Iniciação Científica em contabilidade. Available in: <http://www.congressousp.fipecafi.org/web/ artigos62006/508.pdf>. Access: 20/12/2014.

Churchill, C. (2006). Protecting the poor: a microinsurance compendium Geneva: International Labor Organisation.

Cnseg (2014). Projeção 2013 a 2016. Available in:<http:// www.cnseg.org.br/cnseg/estatisticas/projecoes/>. Access: $27 / 12 / 2014$.
Contador, C. R. (2009). Microsseguros: Série de Pesquisas. V.1 Trad. De Martins, João C, - Rio de Janeiro: FUNENSEG.

Contador, C. R. (2010). Microsseguros: Série de Pesquisas. V.2 Trad. De Martins, João C, - Rio de Janeiro: FUNENSEG.

Contador, C. R. (2011). Microsseguros: Série de Pesquisas. V.3 Trad. De Martins, João C, - Rio de Janeiro: FUNENSEG.

Creswell, J.W. (2003). RESEARCH DESIGN, Qualitative, Quantitative, and Mixed Methods Approaches. Sage Publ. Thousand Oaks, London, 2nd ed. CA.

Dold, A. V. B. (2007). Microfinanças: um desafio socioeconômico. Responsabilidade Social e Ambiental do Sistema Financeiro. Brasília, ano 2, no15, p.1-2.

Ferreira, P. P. (2010). Modelos de precificação e ruína para seguros de curto prazo. Rio de Janeiro: FUNENSEG.

Ferreira, P. P.; Mano, C. C. A. (2009). Aspectos Atuarias e Contábeis das Provisões Técnicas. Rio de Janeiro: FUNENSEG.

Ferreira, W. J. (1985). Coleção introdução à ciência atuarial. Rio de Janeiro: IRB.

Filho, A. C. (2009). Cálculo atuarial aplicado: teoria e aplicações: exercícios resolvidos e propostos. São Paulo: Atlas.

Frischtak, R.; Ramirez, M.; Pinheiro, S.; Beltrão, K. (2010) Tábuas biométricas de mortalidade e sobrevivência: experiência do mercado segurador brasileiro. Rio de Janeiro: FUNENSEG.

Galiza, F. J. dos S. (2011). Economia e seguro: uma introdução. 3 ed. - Rio de Janeiro: FUNENSEG.

Gil, A. C. (1999). Métodos e Técnicas de Pesquisa Social. São Paulo: Atlas.

Gomes, M. M. F.; Okubo, M. H.; Vasconcelos, A. M. N. (2008). Aplicações das Tábuas de Vida para a Previdência Complementar: Estimativas e Comparação com as Tábuas do Mercado. R. Bras. Risco e Seg, Rio de Janeiro. V.4, n.7, p. 1-16 abr/set.

Grupo De Trabalho De Microsseguro Da Susep. (2008). Microsseguro - Relatório II: Identificação das Barreiras Regulatórias no Brasil.

Grupo De Trabalho De Microsseguro Da Susep. (2008). Microsseguro - Relatório I: Definição de Conceito e Identificação de Público-Alvo.

Grupo De Trabalho De Microsseguro Da Susep. (2009). Microsseguro - Relatório III: Identificação das Partes Interessadas no Microsseguro e seus Respectivos Papéis.

Guimarães, S R. (2004). Fundamentação atuarial dos seguros de vida: um estudo comparativo entre os seguros de vida individual e em grupo. Rio de Janeiro: FUNENSEG. 
IBGE (2010). Pesquisa Nacional por Amostra de Domicílio. Available in: <http://www.sidra.ibge.gov.br/bda/ tabela/listabl.asp?Z=pnad\&o=3\&i=P\&c=4020>. Access: 30/12/2014.

Jung, C. F. (2003). Metodologia Científica - Ênfase e Pesquisa Tecnológica. 3 Edição Revisada e Ampliada. Available in: <http://www.jung.pro.br>Access : 02 fev. 2009.

Marcone. M. A; Lakatos. E. M. (2010). Fundamentos de Metodologia do Trabalho Científico. 7 ed. -São Paulo: Atlas.

Merino, A. V; March, J. H; Lozano, I. A; Pérez, C. R. (2002). Proyeccion y estúdio de uma población: el papel de la mortalidad. Madrid: Universidade Complutense de Madrid.

Microinsurance Network (2013). Annual Report. Luxembourg.

Price, R.; Müller, D. (1997). Group life insurance. Cologne: The Cologne Re.

Roth, J.; Mccord, M. J.; Liber, D. (2007). The Landscape of Microinsurance in the World's 100 Poorest Countries. The microinsurance Centre, LLC - April.

Sepulveda, M. P. V.; Afonso, L. E. (2009). Microsseguro Compreensivo Residencial no Brasil: Precificação e Estimativa do Potencial de Mercado. In: 60 Congresso USP Iniciação Científica em Contabilidade, São Paulo.

Silva, I. de O. (2008). Curso de Direito do Seguro. São Paulo: Saraiva.

Souza, S. de (2007). Contabilidade, atuaria e auditoria. 2a ed. - São Paulo: Saraiva.

Teixeira, J. C. A.; Abreu, E. S. (2012). Apresentação Trabalhos Monográficos Conclusão Curso. 10 ed. - Niterói; eduff.

Vieira, J. (2016). Brasil continua com a maior taxa de juros real do mundo. In: O Globo, Caderno de Economia. Available in: <http://oglobo.globo.com/economia/brasil-continuacom-maior-taxa-real-de-juros-do-mundo-14732703>. Access: 30/12/16.

Yunus, M. (2006). O Banqueiro dos Pobres. 1 ed. São Paulo: Ática. 